\title{
PENGARUH MODEL SPORT EDUCATION TERHADAP SIKAP TANGGUNG JAWAB DAN KEMANDIRIAN SISWA
}

\author{
Jurnal Sekolah Dasar, ISSN 2528-2883 Vol. 1 No. 1 Sept 2016 \\ PGSD FKIP UBP Karawang \\ Aang Solahudin Anwar \\ addinu.86@gmail.com
}

\begin{abstract}
Abstrak: Penelitian ini didasari dengan kurangnya inovasi pembelajaran dalam pendidikan jasmani yang hanya didominasi oleh model pembelajaran konvensional. Metode yang digunakan dalam penelitian ini adalah Quasi Eksperimental Design dengan populasi Siswa Putra SMA Nurul Fikri Boarding School Lembang Bandung berjumlah 180 orang peserta sedangkan subjek penelitian dipilih dengan teknik non random sampling, sampelnya sebanyak 30 orang siswa SMA Nurul Fikri dengan rincian siswa kelas XI Kelompok SEM 15 orang dan kelompok Konvensional 15 Orang. Berdasarkan penelitian yang telah dilakukan, didapatkan beberapa hasil penelitiam sebagai berikut,1). SEM berpengaruh terhadap sikap tanggung jawab, 2) Model konvensional berpengaruh terhadap sikap tanggung jawab, 3). SEM berpengaruh terhadap sikap kemandirian, 4). Model Konvensional berpengaruh terhadap sikap kemandirian, 5). Kedua model pembelajaran ini berpengaruh terhadap pembentukan sikap tanggung jawab, 6). Kedua model pembelajaran ini berpengaruh terhadap pembentukan sikap kemandirian.
\end{abstract}

Kata kunci: Model Sport Education, Sikap Tanggung Jawab, Kemandirian Siswa

Abstract: The research was based on the lack of innovation learning in physical education dominated by conventional learning models. The method used in this study was Quasi Experimental Design with a population of students Men SMA Nurul Fikri Boarding School Lembang, Bandung totaling 180 participants while the subjects were selected by using non-random sampling, the sample of 30 high school students Nurul Fikri with details of class XI student of Group SEM Conventional group of 15 people and 15 people. Based on the research that has been done, get some results penelitiam as follows, 1). SEM affect the attitude of responsibility, 2) Conventional models affect the attitude of responsibility, 3). SEM affect the attitude of self-reliance, 4). Conventional models affect the attitude of self-reliance, 5). Both this model affect the formation of attitudes of responsibility, 6). Both this model affect the formation of self-reliant attitude.

Keywords: Model Sport Education, Attitude Responsibility, Independence Students 


\section{PENDAHULUAN}

Keberhasilan pendidikan di sekolah banyak ditentukan oleh keberhasilan belajar mengajar. Belajar menduduki peran yang sangat penting baik dalam konteks kehidupan umat manusia dan konteks kehidupan semua mahluk hidup lainnya di bumi ini, agar kehidupan mereka dapat terus berlangsung. Binatang yang secara alami diberi insting untuk mempertahankan hidupnya, ternyata juga tidak lepas dan keharusan belajar. Sebagaimana disimpulkan oleh Hergenhehn dan Olson (dalam Rini 2008:2), bahwa "Kemampuan one-trial learning (belajar coba satu kali) pada binatang merupakan pelengkap dari instingnya agar mereka dapat mempertahankan kehidupan dirinya". Demikian juga halnya dengan manusia, agar mereka bisa terus mempertahankan hidupnya mereka dituntut untuk terus belajar dan belajar.

Belajar ditunjukkan dengan adanya perubahan dalam perilaku, atau dengan kata lain, hasil dari belajar harus selalu diterjemahkan ke dalam perilaku yang dapat diamati. Artinya, setelah seseorang mengalami proses belajar, ia akan dapat melakukan sesuatu yang sebelumnya tidak bisa dilakukan. Mempelajari perilaku agar dapat memperkirakan adanya proses yang dipercayai menjadi sebab perubahan perilaku yang sedang diamati, proses tersebut adalah belajar.

Demikian juga dengan belajar dalam kelas pendidikan jasmani meskipun pada kenyataannya tujuan pendidikan jasmani di atas belum sepenuhnya dapat diwujudkan, banyak Siswa siswi yang diharapkan dapat berbuat sesuai dengan tujuan tersebut malah sebaliknya, banyak remaja melakukukan perbuatan negatif yang dapat merugikan dirinya maupun orang lain. Dalam Rahman (2012: 4) "Kecenderungan perilaku ini diperparah dengan maraknya kejadian remaja putra dan putri yang terjebak dalam narkoba dan pergaulan bebas, walaupun masih dalam tarap wajar dan dianggap sebagai sesuatu yang lumrah". Tetapi apakah hal itu tetap didiamkan? Jika sesuatu perbuatan negatif (mudharat) dibiarkan dan tidak diperbaiki maka itu dapat merupakan sebuah gejala seosial dan berdampak pada budaya. Secara tidak disadari bahwa perbuatan tersebut menjadikan berdosa (dosa bersama) jika tidak dihilangkan. 
Untuk menanamkan sikap tanggung jawab perlu upaya yang dilakukan oleh beberapa pihak, diantaranya pihak Orang tua sebagai ummul madrosah pemegang pendidikan pertama kali anak dalam keluarga. Kedua pihak sekolah, dalam hal ini sekolah mempunyai peranan yang penting setelah keluarga, diharapkan dengan siswa memperoleh pendidikan di sekolah sesuai apa yang diharapkan oleh keluarga. Ketiga lingkungan, ini merupakan faktor yang penting yang harus menjadi perhatian karena perkembangan perilaku siswa (anak didik) dipengaruhi oleh lingkungan, keturunan, dan kematangan/P = f $(\mathrm{H}, \mathrm{E}, \mathrm{T})$, menurut Abin Syamsudin (2012:24)

"yang dimaksud dengan lingkungan disini dapat diartikan sebagai berikut: a). Lingkungan Objektif (umgebung = segala sesuatu yang ada disekitar individu dan secara potensial dapat melahirkan S(stimulus/perangsang)). b). lingkungan efektif (segala sesuatu yang aktual akan merangsang organisme karena sesuai dengan dunia pribadinya (W= umwelt sehingga menimbulkan kesadaran tertentu pada diri O dan ia merespon (R) terhadapnya)".

Melalui sistem pengaruh lingkungan seperti sekarang ini, cukup sulit bagi keluarga pada saat ini hanya menekankan pendidikan di salah satu lini saja. Sehebat apapun keluarga menyusun sistem pertahanan diri, anak-anak tetap akan menjadi santapan dunia yang serba modern. Kalau tidak sekarang ya akhirnya akan bersentuhan juga. Menyerahkan sepenuhnya pendidikan anak kepada sekolah juga bukan segala-galanya. Pendidikan dijaman ini amat sulit mencari yang "kaffah lahir dan bathin" serta terjangkau biayanya oleh kebanyakan orang tua.

Oleh karena itu untuk menanamkan sikap tanggung jawab dan kemandirian perlu dipadukan antara lingkungan belajar dan model pendidikan yang mengarahkan kepada tujuan tersebut. Upaya dalam mewujudkan sekolah yang mempunyai nuansa pendidikan kaffah lahir bathin yakni dengan adanya sekolah boarding atau sekolah yang berasrama dan memuat nilai-nilai kepesantrenan. Upaya yang sifatnya mengarahkan pada upaya mengkemas pendidikan lahir adalah dengan menerapkan pendidikan jasmani dengan menyuguhkan ke dalam bentuk model pembelajaran pendidikan jasmani. Good dan Brophy (1990;142) menjelaskan bahwa: "pemakaian strategi atau pendekatan pembelajaran yang tepat 
akan memungkinkan beragam tujuan proses pembelajaran lebih mudah untuk dicapai."

Bekenaan dengan pembentukan sikap dalam proses pendidikan jasmani penulis tertarik untuk meneliti pengaruh sikap yang diberikan melalui aktifitas fisik dalam proses pembelajaran dengan Model Sport Education. Sport Education sendiri merupakan model pembelajaran yang digagas oleh Sidentop pada tahun 1994 di Negeri Paman Sam (Amerika), dalam prosesnya Sport Education Model (SEM) lebih banyak memberikan kesempatan kepada anak didik untuk mengatur, mempersiapkan dan melaksanakan sebuah aktivitas pembelajaran Sport Education yang dikemas dalam sebuah event pertandingan.

SEM merupakan model yang menyuguhkan pembelajaran dalam bentuk kompetisi yang di dalamnya terdapat tujuan. Menurut Sidentop mengenai Sport Education Model yang dialih bahasakan oleh Mahendra dalam siklus online (mahendra@blogspot.com/implementasi sport education.html) pada 4 Maret 2013 tujuan Model Sport Education adalah :

a. Mengembangkan keterampilan dan kebugaran.

b. Menghargai dan dapat melakukan permainan strategis dalam olahraga.

c. Berperan serta secara layak sesuai dengan tahap perkembangannya.

d. Berbagi peran dalam perencanaan dan administrasi program olahraga.

e. Memberikan dan mengembangkan kepemimpinan yang bertanggung jawab.

f. Bekerja secara efektif dalam kelompok untuk mencapai tujuan bersama.

g. Menghargai ritual dan konvensi keunikan makna dari setiap cabang olahraga.

h. Mengembangkan dan menerapkan pengetahuan tentang perwasitan, penilaian dan pelatihan.

Model pembelajaran Sport Education adalah model pembelajaran dalam pendidikan jasmani yang dibentuk dalam format kompetisi olahraga yang bertujuan untuk mendidik siswa menjadi pemain dalam arti sesungguhnya serta membantu mereka menjadi olahragawan yang kompeten (Susanto 2010:1).

Perlman (2010) mengungkapkan perbedaan antara SEM dengan Model Tradisional sebagai berikut : 
Tabel 1.

Perbandingan Sport Education Model dan Traditional Model

\begin{tabular}{|l|l|}
\hline \multicolumn{1}{|c|}{ SEM } & \multicolumn{1}{|c|}{ TRADISIONAL } \\
\hline $\begin{array}{l}\text { Pembelajaran dengan Pengembangan } \\
\text { Skill/ tactical. }\end{array}$ & $\begin{array}{l}\text { Pendekatan pembelajaran Skill - } \\
\text { drill } \text { - game }\end{array}$ \\
\hline $\begin{array}{l}\text { Pembelajaran dilaksanakan dg praktek } \\
\text { tim dan di akhiri dengan permainan } \\
\text { kecil dan sisipan }\end{array}$ & $\begin{array}{l}\text { Pembelajaran bersumber dari guru } \\
\text { sebagai pengatur pola pembelajaran }\end{array}$ \\
\hline $\begin{array}{l}\text { Pemanasan dilakukan oleh anggota } \\
\text { team }\end{array}$ & $\begin{array}{l}\text { Pemanasan dikembangkan dan di } \\
\text { implementasikan pada seluruh } \\
\text { siswa/pemanasan secara kolosal, } \\
\text { dipimpin oleh siswa }\end{array}$ \\
\hline $\begin{array}{l}\text { Bentuk dan aplikasi Pembelajaran } \\
\text { skill/taktik dilksanakan oleh regu/tim } \\
\text { pada sesi latihan dan selama proses } \\
\text { pembelajaran (pre season-culminating } \\
\text { event) }\end{array}$ & $\begin{array}{l}\text { Pembelajaran dengan pola larihan } \\
\text { skill dan drill (pegulangan latihan) }\end{array}$ \\
\hline $\begin{array}{l}\text { bentuk pembelajaran dengan } \\
\text { Intra/interteam game play } \\
\text { Intra/interteam game play allowed } \\
\text { teams time to practice) }\end{array}$ & $\begin{array}{l}\text { Bentuk permainan mengarah pada } \\
\text { olahraga sebenarnya dan dengan } \\
\text { pola kompetisi }\end{array}$ \\
\hline $\begin{array}{l}\text { Siswa dan guru bersama dalam } \\
\text { membentuk nilai-nilai fair play }\end{array}$ & $\begin{array}{l}\text { Guru membuat dan menentukan } \\
\text { bentuk peraturan permaianan }\end{array}$ \\
\hline $\begin{array}{l}\text { Pembagian tugas/peran, pembagian } \\
\text { tugas/tanggung jawab }\end{array}$ & $\begin{array}{l}\text { Tidak ada pembagian peran dan } \\
\text { peraturan siswa }\end{array}$ \\
\hline $\begin{array}{l}\text { Akhir pembelajaran diakhiri dengan } \\
\text { akhir dari kompetisi/turnamen }\end{array}$ & $\begin{array}{l}\text { Akhir pembelajaran diakhiri dengan } \\
\text { menang dan kalah }\end{array}$ \\
\hline $\begin{array}{l}\text { Bentuk perayaan dan penghargaan } \\
\text { diakhir /pasca kompetisi }\end{array}$ & Tidak ada bentuk perayaan \\
\hline
\end{tabular}

Adapun sikap bertanggung jawab yang dimiliki seseorang tidak bisa muncul begitu saja dengan sendirinya tanpa dikembangkan. Tanggung jawab akan muncul apabila disadari oleh karakter yang baik, dalam karakter yang baik akan tumbuh pada diri anak bila dia terbiasa dengan melakukan hal -hal yang baik pula. Lhikoma (1992) dalam Rochman (2012: 35), menyatakan bahwa "good character consist of knowing the good, desiring the good and doing the good habbits of the mind, habbits of the heart and habbits of action". Kemudian pentingnya peran keteladanan dalam hal sikap tanggung jawab ini, dalam hal ini guru mutlak 
memberikan keteladan dalam memikul tanggung jawab, karena tidak mungkin guru mengamanahkan sikap tanggung jawab kepada siswa tanpa dia sendiri mampu melaksanakan tanggung jawab tersebut.

Dalam teori kemandirian yang dikembangkan Steinberg (1995) istilah independence dan autonomy sering disejajarartikan secara silih berganti (interchangeable) sesuai dengan konsep kedua istilah tersebut. Meski secara umum kedua istilah tersebut memiliki arti yang sama yakni kemandirian, tetapi sesungguhnya secara konseptual kedua istilah tersebut berbeda. Secara leksikal independence berarti kemerdekaan atau kebebasan (Kamus Inggris-Indonesia). Secara konseptual independence mengacu kepada kapasitas individu untuk memperlakukan diri sendiri. Steinberg (1995:286) menyatakannya independence generally refers to individuals' capacity to behaveon their own.

Sikap mandiri merupakan sikap yang harus dimiliki oleh semua orang. Sebagai manusia yang diciptakan oleh Allah SWT sebagai makhluk sosial dan makhluk individu. Manusia dicipatakan sebagai makhluk sosial, manusia diperintahkan oleh Allah untuk bersosialisasi, menjalin silaturrahmi melaksanakan ibadah ghoir mahdoh dengan manusia lain, sebagaimana yang di firmankan oleh Allah Swt dalam Alqur'anul Kariem Surat Ali Imron yang berbunyi “ Mereka diliputi kehinaan di mana saja mereka berada, kecuali jika mereka berpegang kepada tali (agama) Allah dan tali (perjanjian) dengan manusia, dan mereka kembali mendapat kemurkaan dari Allah dan mereka diliputi kerendahan. Yang demikian itu karena mereka kafir kepada ayat-ayat Allah dan membunuh para Nabi tanpa alasan yang benar, yang demikian itu disebabkan mereka durhaka dan melampaui batas. (QS. 3:112)". Maksud dari ayat tersebut menitik beratkan kalimat hablun minallah wahablun minannass yakni pada hubungan manusia dengan Allah dan hubungan manusia dengan manusia.

\section{METODE PENELITIAN}

Metode penelitian yang digunakan dalam penelitian ini adalah mtode Quasi Experimental Design. Sugiyono (2010:114) mendefinisikan quasi eksperimen adalah merupakan pengembangan dari true experimental design, yang sulit 
dilaksanakan. Desain ini mempunyai kelompok kontrol, tetapi tidak dapat berfungsi sepenuhnya untuk mengontrol variabel-variabel luar yang mempengaruhi pelaksanaan experimen/suatu cara untuk mencari hubungan sebab akibat (hubungan kausal) antara dua faktor yang sengaja ditimbulkan oleh peneliti dengan mengeliminasi atau mengurangi atau menyisihkan faktor-faktor lain yang mengganggu.

Proses dalam penelitian ini akan mengungkap tentang dua variabel yakni sport education model (SEM) dan model konvensional yang akan di lihat pengaruhnya melalui variabel lain yakni dalam sikap bertanggung jawab dan kemandirian. Metode yang digunakan ini lebih mentitik beratkan pada penelitian korelasional yaitu suatu penelitian untuk mengetahui mengenai suatu hubungan dan tingkat hubungan antara dua variabel atau lebih tanpa ada upaya untuk mempengaruhi variabel tersebut sehingga tidak terdapat manipulasi variabel (Fraenkel dan Wallen, 2008:328). Penelitian ini terdiri dari dua variabel yaitu variabel bebas sport education model (SEM) dan model konvensional, sedangkan variabel terikatnya adalah sikap bertanggung jawab dan kemandirian. Dari penelusuran permasalahan real di lapangan sehingga memunculkan berbagai pertanyaan, selanjutnya melakukan pelusuran beragam data empirik dan teoretik sebagai landasan kerangka berpikir untuk menentukan perumusan hipotesis dengan mengacu pada kerangka berfikir dan kajia empiric serta teoretik. Setelah menetukan teori yang mendukung dan tapat berikutnya adalah penentuan metode penelitian berkenaan dengan sample, instrumen, desain dan prosedur penelitian (method, subject, instruments, design \& procedure). Dalam tahap ini peneliti melakukan eksperimen terhadap objek yang akan diteliti dengan meneliti objek penelitian sport education model (SEM) yang menjadi variabel bebas terhadap sikap tanggung jawab dan kemandirian sebagai variabel terikat. Proses tersebut akan dilakukan selama 12 pertemuan dengan melakukan penelitian terhadap siswa SMA kelas XI yang diberi perlakuan dengan aktifitas penggunaan model Sport education dengan memberikan pembelajaran yang dikemas dengan program perlakuan. Sebelum siswa naracoba diberikan program terlebih dahulu dilakukan pretest untuk mengetahui kondisi awal sikap tanggung jawab dan kemandirian. Setelah pretes dilakukan setelah itu barulah 
diberikan perlakuan sport education model kepada kelompok eksperimen dan model konvensional diberikan kepada kelompok kontrol.

Setelah tahap tersebut selesai dilakukan maka selanjutnya dilakukan Analisis dan interpretasi data. Dalam tahap peneliti melakukan analisis penyimpulan data dan melakukan interpretasi data apakah program tersebut berhasil dan sesuai.

Pada penelitian ini penulis melaksanakan penelitian yang bertempat di sekolah SMA Nurul Fikri Boarding School Cibodas Lembang dibawah naungan Yayasan pesantren pendidikan Islam yang merupakan sekolah dengan konsep asrama yang memadukan pendidikan umum dengan pendidikan islam dengan motto Mencetak Generasi Sholeh, Cerdas dan Mampu Memimpin.

Penelitian ini dilakukan pada semester kedua tahun ajaran 2013/ 2014 dengan pertemuan 90 menit pembelajaran di pagi hari atau sore sebanyak 4 kali perminggunya sehingga dalam waktu kurang satu bulan menjadi 12 pertemuan tetapi hal ini dapat dikondisikan sesuai dengan kebutuhan peneliti.

Table 2

Perbedaan Skenario Pembelajaran Sport Education Model dan Tradisional

\begin{tabular}{|c|c|c|}
\hline Sekenario & \multicolumn{2}{|c|}{ Model pembelajaran } \\
\hline Rutinitas & SEM & Tradisional \\
\hline Pendahuluan & $\begin{array}{l}\text { 1. } \begin{array}{l}\text { Berbaris, berdoa, } \\
\text { mengabsen. }\end{array} \\
\text { 2. Pemanasan dilakukan oleh } \\
\text { kelompok dan dipimpin } \\
\text { oleh kelompok regu }\end{array}$ & 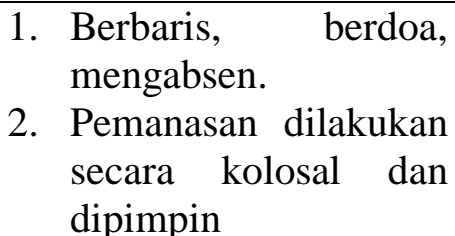 \\
\hline \multirow[t]{2}{*}{ Inti } & $\begin{array}{l}\text { 1. Guru mempersilahkan } \\
\text { kapten/pemimpin kelompok } \\
\text { untuk memimpin rekannya } \\
\text { latihan berbagai variasi } \\
\text { passing untuk permainan } \\
\text { futsal.guru hanya } \\
\text { mengawasi latihan masing- } \\
\text { masing kelompok/regu.Dan } \\
\text { memberi masukan jiak ada } \\
\text { tim yang bertanya. }\end{array}$ & $\begin{array}{l}\text { 1. Guru } \\
\text { menginstruksikan } \\
\text { siswa untuk } \\
\text { melakukan teknik } \\
\text { pembelajaran passing, } \\
\text { berpasangan } 2 \text { orang } \\
\text { dan saling berhadapan } \\
\text { untuk melakukan } \\
\text { passing bola saling } \\
\text { bergantian. } \\
\text { 2. Setelah sesi latihan } \\
\text { selesai guru membagi. }\end{array}$ \\
\hline & \multicolumn{2}{|c|}{ Model Pembelajaran } \\
\hline Kegiatan & SEM & Konvensional \\
\hline Inti & $\begin{array}{l}\text { 2. Setelah sesi latihan selesai, } \\
\text { guru mempersilahkan }\end{array}$ & $\begin{array}{l}\text { 3. siswa kedalam } 2-4 \\
\text { kelompok untuk }\end{array}$ \\
\hline
\end{tabular}




\begin{tabular}{|c|c|c|c|}
\hline & $\begin{array}{l}\text { kepada kapten tim untuk } \\
\text { melakukan games } 2 \text { vs } 2 \\
\text { atau } 3 \text { vs } 3\end{array}$ & & $\begin{array}{l}\text { melakukan } \\
\text { permainan/simulasi } \\
\text { games } 5 \text { vs } 5\end{array}$ \\
\hline Penutup & 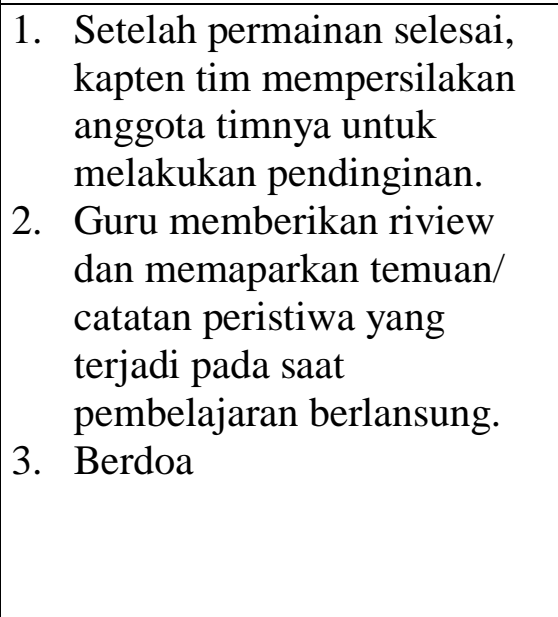 & & $\begin{array}{l}\text { Siswa dikondisikan } \\
\text { untuk melakukan } \\
\text { pendinginan di pimpin } \\
\text { oleh guru/guru } \\
\text { mempercayakan } \\
\text { kepada siswa yang } \\
\text { dianggap lebih } \\
\text { mampu. } \\
\text { Guru melakukan } \\
\text { riview pembelajaran } \\
\text { dan mengakhiri } \\
\text { pemblejaran } \\
\text { Berdoa }\end{array}$ \\
\hline
\end{tabular}

Instrumen yang digunakan dalam penelitian ini ada dua instrument yang pertama instumen untuk mengukur sikap tanggung jawab dan yang kedua untuk mengukur kemampuan sikap kemandirian. Instrument yang digunakan untuk menentukan sikap tanggung jawab adalah dengan menggunakan angket yang menggunkan Skala Likert. Sedangkan untuk menentukan jiwa mandiri peneliti menggunakan instrument kemandirian untuk remaja yang diadopsi dari Amdani Sarjun ketua ABKIN (2011) mengenai program bimbingan kelompok untuk meningkatkan kemandirian siswa yang terdiri dari 78 pertanyaan dengan empat pilihan jawaban sangat setuju (SS), Setuju (S), Tidak Setuju (TS), Sangat Tidak Setuju (STS).

Setelah data dari tes dari angket terkumpul, langkah selanjutnya adalah mengolah dan menganalisis data data menggunakan rumus Statistik yang disusun oleh Sudjana (1984) dan Furqon (2010). Langkah-langkah pengolahan data tersebut ditempuh dengan prodesur sebagai berikut:

a. Tabulasi Data

b. Menghitung nilai rata - rata dari masing - masing butir tes

$$
\bar{X}=\frac{\Sigma X i}{n}
$$

Ket:

$$
\bar{X}=\text { Skor rata-rata yang dicari/mean }
$$


$\Sigma=$ Jumlah dari Xi

$X i=$ Skor mentah

c. Mencari simpangan baku dari setiap tes

$$
\sqrt{\frac{s \bar{\Sigma}(X i-X)^{2}}{n-1}}
$$

Ket:

$\mathrm{S}$ = Simpangan baku yang dicari

$X i=$ Skor mentah

$X=$ Rata-rata dari skor mentah

$\mathrm{n} \quad=$ Jumlah sampel

d. mencari nilai standar deviasi (s) dari masing - masing butir tes.

e. membuat skor standar

f. Hasil uji beda skor pretes dan post test dari sikap tanggung jawab dan kemandirian menggunakan Uji t

Hasil pretest dan postest angket dengan Uji t menggunakan SPSS versi 20.

\section{HASIL PENELITIAN}

Pada deskripsi data sikap tanggung jawab, penulis sajikan gambaran secara umum mengenai data hasil penelitian. Data yang disajikan adalah jumlah sampel, rata-rata, standar deviasi, atau simpangan baku, varians, skor terendah dan tertinggi dari masing-masing kelompok. Data pada table dibawah ini memberikan gambaran mengenai data yang diperoleh dari kelompok sport education model dan model Konvensional. Data digambarkan dengan format penyajian tebel dan gambar berupa grafik seperti dibawah ini.

Table 3

Deskripsi data sikap Tanggung Jawab kelompok Sport Education Model dan Kelompok konvnesional secara keseluruhan

\begin{tabular}{|c|c|c|c|c|c|c|c|c|c|c|c|}
\hline \multirow[t]{2}{*}{ Data } & \multirow[t]{2}{*}{$\mathbf{N}$} & \multicolumn{2}{|c|}{ Rata } & \multicolumn{2}{|c|}{ S dev } & \multicolumn{2}{|c|}{ Var } & \multicolumn{2}{|c|}{ S rendah } & \multicolumn{2}{|c|}{ S tinggi } \\
\hline & & Pre & Post & Pre & Post & Pre & Post & Pre & Post & Pre & Post \\
\hline
\end{tabular}




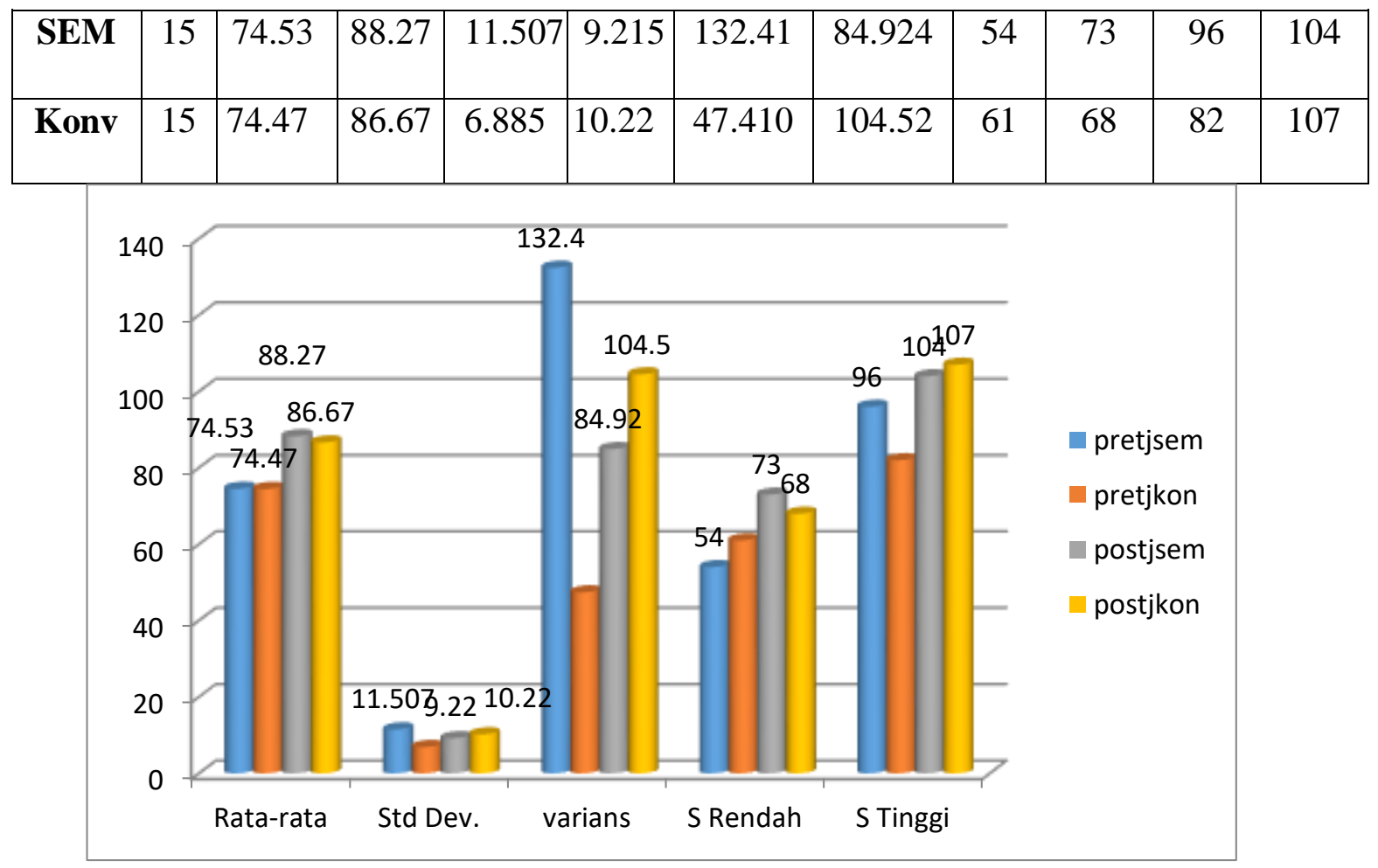

\section{Gambar 1}

\section{Deskripsi data sikap Tanggung Jawab kelompok Sport Education Model dan} Kelompok konvnesional secara keseluruhan

Dari deskripsi data sikap kemandirian di atas dapat dilihat bahwa terjadi peningkatan rata-rata tes awal jika dibanding dengan tes akhir dari masing-masing kelompok walau peningkatanya tidak terlalu tinggi. Pada pretest sikap bertanggung jawab kelompok SEM menunjukan rata-rata 74.53 terjadi peningkatan angka 3.74 pada posttes menjadi 88.27. Pada pretest sikap bertanggung jawab di kelompok konvensional menunjukan rata-rata 74.47 terjadi peningkatan pada posttes menjadi 86.67 hal ini menunjukan ada kenaikan secara signifikan sebesar 12.20.

Table 4

Deskripsi data sikap kemandirian kelompok Sport Education Model dan Kelompok konvnesional secara keseluruhan

\begin{tabular}{|c|c|c|c|c|c|c|c|c|c|c|c|}
\hline \multirow{2}{*}{ data } & \multirow{2}{*}{$\mathbf{N}$} & \multicolumn{2}{|c|}{ Rata } & \multicolumn{2}{c|}{ S dev } & \multicolumn{2}{c|}{ Var } & \multicolumn{2}{c|}{ S rendah } & \multicolumn{2}{c|}{ S tinggi } \\
\cline { 3 - 12 } & & pre & Post & Pre & Post & Pre & Post & Pre & Post & Pre & Post \\
\hline SEM & $\mathbf{1 5}$ & 160.80 & 195.87 & 16.072 & 15.165 & 258.314 & 150.165 & 124 & 180 & 181 & 237 \\
\hline Konv & $\mathbf{1 5}$ & 162.40 & 192.47 & 10.716 & 13.658 & 114.829 & 229.981 & 128 & 174 & 212 & 174 \\
\hline
\end{tabular}




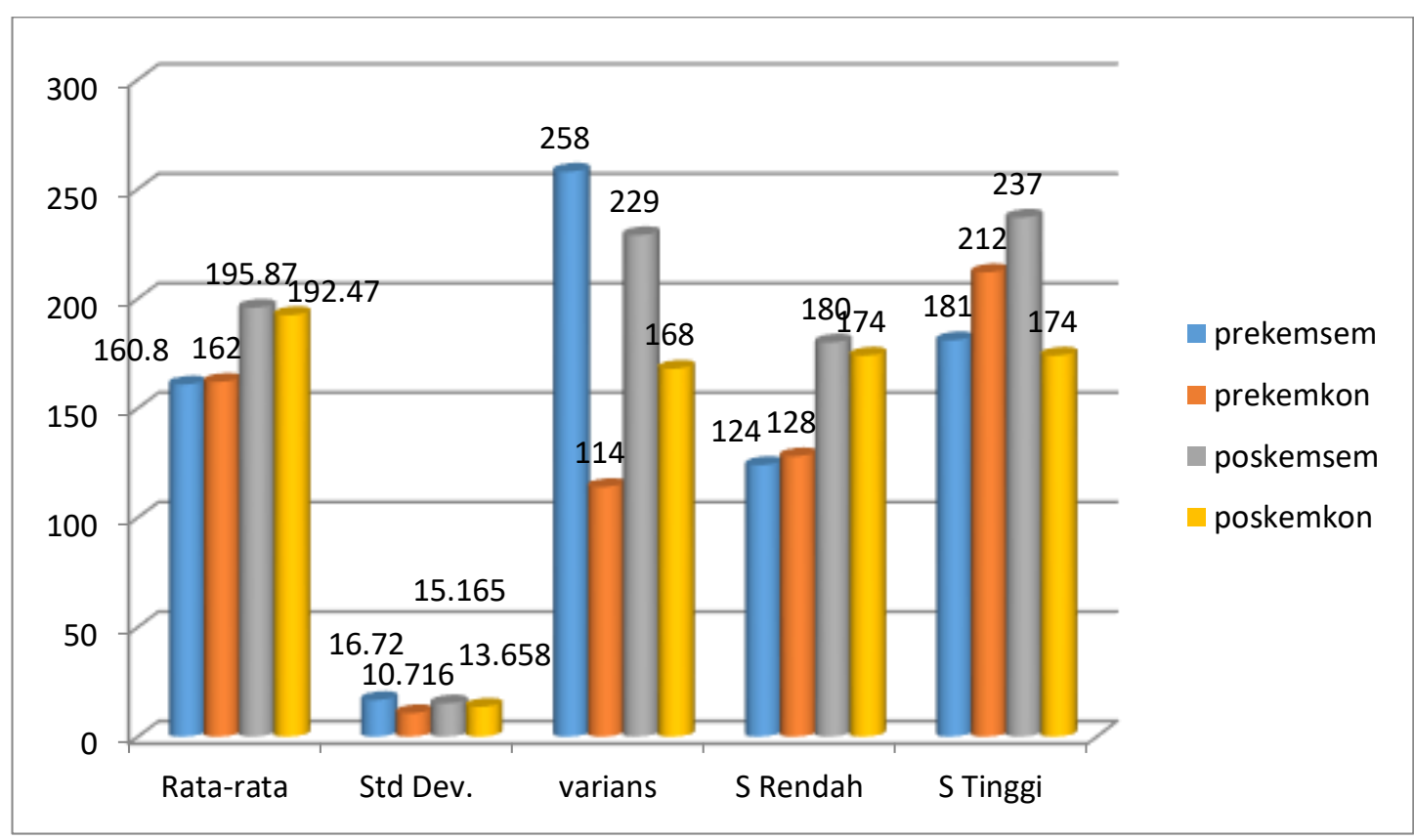

Gambar 2

Deskripsi data sikap kemandirian kelompok Sport Education Model dan Kelompok konvnesional secara keseluruhan

Dari deskripsi data sikap kemandirian di atas dapat dilihat bahwa terjadi peningkatan rata-rata tes awal jika dibanding dengan tes akhir dari masing-masing kelompok walau peningkatanya tidak terlalu tinggi. Pada pretest kemandirian kelompok SEM menunjukan rata-rata 160.8 terjadi peningkatan angka 35.79 pada posttes menjadi 195.87. Pada pretest kemandirian di kelompok konvensional menunjukan rata-rata 162 terjadi peningkatan pada posttes menjadi 192.47 hal ini menunjukan ada kenaikan secara signifikan sebesar 30,47.

Selain menyajikan data secara keseluruhan dari tes awal dan tes akhir sikap tenggung jawab pada masing-masing kelompok, penulis juga menyajikan data nilai selisih/ beda hasil tes awal dan tes akhir pada masing-masing kelompok. Hasil deskripsi selisih/beda Antara sikap tanggung jawab dan kemandirian pada kelompok SEM dan Konvensional. Di bawah ini akan dipaparkan secara terpisah Antara sikap bertanggung jawab dan kemandirian yang disajikan dalam tabel berikutnya. 
Table 5

Deskripsi data selsisih /beda dari setiap kelompok secara keseluruhan sikap Tanggung Jawab

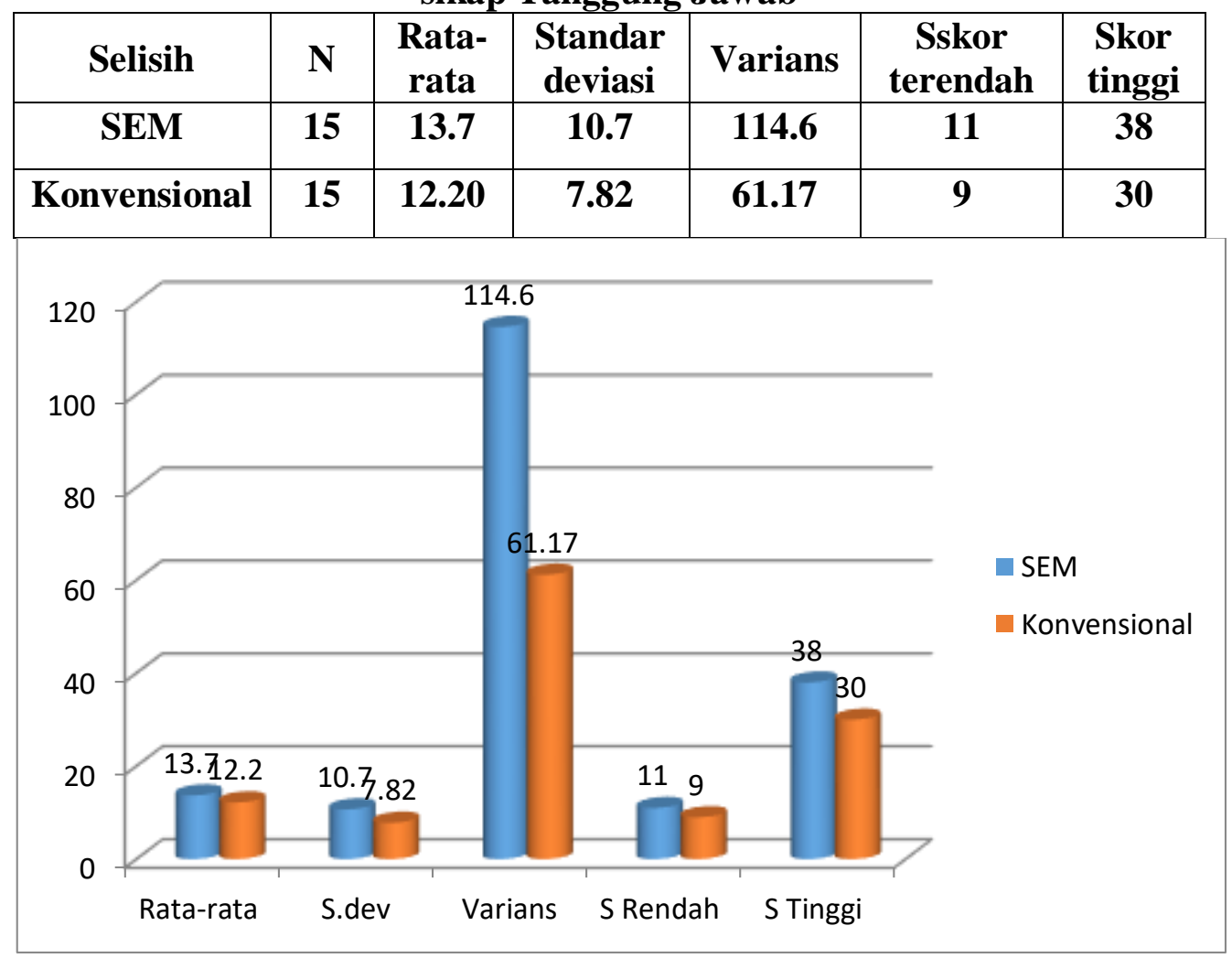

Gambar 3 Deskripsi data Selsisih /beda dari Setiap Kelompok Secara Keseluruhan sikap Tanggung Jawab

Dari hasil deskripsi selisih /beda untuk sikap tanggung jawab pada kelompok SEM dan konvensional terdapat beberapa selisih yang berbeda antara keduanya, tercatat pada kelompok sem terjadi selisih yang lebih besar dibanding kelompok konvensional. Rata-rata kelompok SEM 13.7 konvensional 12.2 terdapat kenaikan 0.5. Variansi kelompok SEM 144 kelompok konvensional 61.17 terdapat kenaikan 83.43. Langkah selanjutnya setelah melakukan pengujian hipotesis penelitian menggunakan Uji t melalui uji paired sampel tes dengan analisis SPSS serie 20 adapun hasilnya sebagai berikut: 
Tabel 6

Pengujian Hipotesis Sikap Tanggung Jawab dengan Menggunakan Uji T.

1. Paired Samples Statistics

\begin{tabular}{|rl|r|r|r|r|}
\hline & & \multicolumn{1}{c|}{ Mean } & \multicolumn{1}{c|}{ N } & \multicolumn{1}{c|}{ Std. Deviation } & \multicolumn{1}{c|}{ Std. Error Mean } \\
\hline \multirow{2}{*}{ Pair 1 } & PRETJSEM & 74.5333 & 15 & 11.50693 & 2.97108 \\
& POSTJSEM & 88.2667 & 15 & 9.21541 & 2.37941 \\
\hline
\end{tabular}

2. Paired Samples Correlations

\begin{tabular}{|ll|c|c|c|}
\hline & $\mathrm{N}$ & Correlation & Sig. \\
\hline Pair 1 & PRETJSEM \& POSTJSEM & 15 & .484 & .067 \\
\hline
\end{tabular}

3. Paired Samples Test

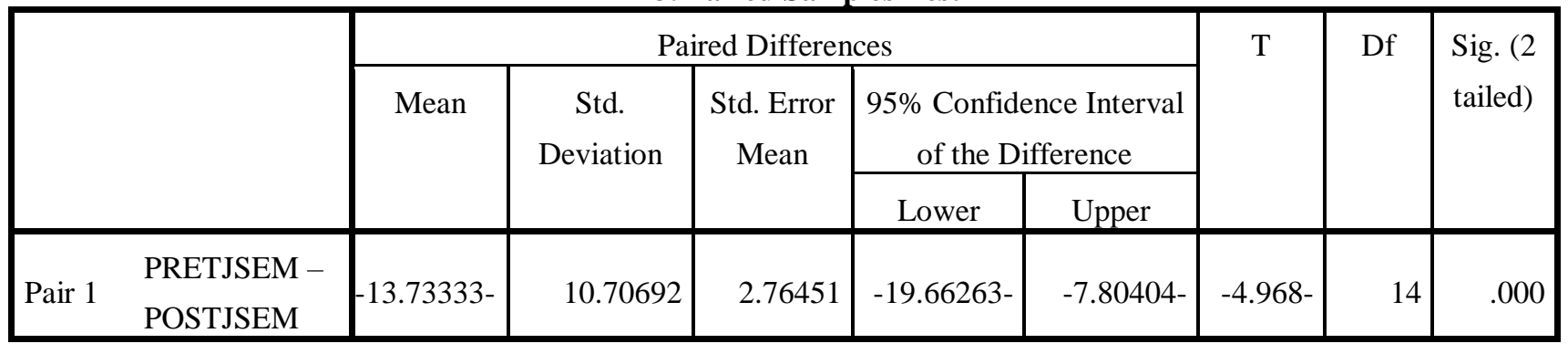

Berdasarkan hasil perhitungan

Paired Sample Test mengenai perbedaan hasil pretes dan postes sikap tanggung jawab pada kelompok
Sport Education Model. Diketahui ada perbedaan hasil pretes dan posttest sikap tanggung jawab pada kelompok Sport Education Model.

Tabel 7

Pengujian Hipotesis Sikap Tanggung jawab pada Kelompok Model Pembelajaran Konvensional dengan Menggunakan Uji T

1. Paired Samples Statistics

\begin{tabular}{|cc|c|c|c|c|}
\hline & & Mean & $\mathrm{N}$ & $\begin{array}{c}\text { Std. } \\
\text { Deviation }\end{array}$ & Std. Error Mean \\
\hline \multirow{2}{*}{ Pair 1 } & PRETJKON & 74.47 & 15 & 6.885 & 1.778 \\
& POSTJKON & 86.67 & 15 & 10.224 & 2.640 \\
\hline
\end{tabular}

2. Paired Samples Correlations

\begin{tabular}{|ll|c|c|c|}
\hline & $\mathrm{N}$ & Correlation & Sig. \\
\hline Pair 1 & $\begin{array}{l}\text { PRETJKON \& } \\
\text { POSTJKON }\end{array}$ & 15 & .645 & .009 \\
\hline
\end{tabular}




\section{Paired Samples Test}

\begin{tabular}{|c|c|c|c|c|c|c|c|c|c|}
\hline & & \multicolumn{5}{|c|}{ Paired Differences } & \multirow[t]{3}{*}{$\mathrm{T}$} & \multirow[t]{3}{*}{ df } & \multirow{3}{*}{$\begin{array}{l}\text { Sig. (2- } \\
\text { tailed) }\end{array}$} \\
\hline & & \multirow[t]{2}{*}{ Mean } & \multirow[t]{2}{*}{$\begin{array}{c}\text { Std. } \\
\text { Deviation }\end{array}$} & \multirow{2}{*}{$\begin{array}{l}\text { Std. } \\
\text { Error } \\
\text { Mean }\end{array}$} & \multicolumn{2}{|c|}{$\begin{array}{l}\text { 95\% Confidence Interval of } \\
\text { the Difference }\end{array}$} & & & \\
\hline & & & & & Lower & Upper & & & \\
\hline Pair 1 & $\begin{array}{l}\text { PRETJK } \\
\text { ON - } \\
\text { POSTJK } \\
\text { ON }\end{array}$ & -12.200 & 7.821 & 2.019 & $-16.531-$ & $-7.869-$ & $6.041-$ & 14 & .000 \\
\hline
\end{tabular}

Berdasarkan hasil Berdasarkan tabel di atas diketahui

perhitungan Paired Sample Test pada bahwa nilai T -6.041 dan signifikansi tabel 12 bagian 3 mengenai $0,000<0,005$. Artinya $\mathrm{H}_{1}$ diterima perbedaan hasil pretes dan postes yang menyatakan bahwa terdapat sikap tanggung jawab pada perbedaan yang signifikan hasil kelompok model pembelajaran pretest dan posttes sikap Tanggung Konvensional. Diketahui ada perbedaan hasil pretes dan posttest sikap tanggung jawab pada Jawab siswa yang mendapatkan perlakuan Model pembelajaran Konvensional.

kelompok Model Konvensioal.

\section{Tabel 8}

Pengujian Hipotesis SEM Terhadap Sikap Kemandirian dengan Menggunakan Uji T.

1. Paired Samples Statistics

\begin{tabular}{|c|c|c|c|c|c|}
\hline & & Mean & $\mathrm{N}$ & Std. Deviation & Std. Error Mean \\
\hline Pair & $\begin{array}{l}\text { PREKEMSE } \\
\mathrm{M}\end{array}$ & $\begin{array}{c}160.8 \\
0\end{array}$ & 15 & 16.072 & 4.150 \\
\hline 1 & $\begin{array}{l}\text { POSKEMSE } \\
\mathrm{M}\end{array}$ & $\begin{array}{c}195.8 \\
7 \\
\end{array}$ & 15 & 15.165 & 3.916 \\
\hline
\end{tabular}


2. Paired Samples Correlations

\begin{tabular}{|ll|r|r|r|}
\hline & & $\mathrm{N}$ & \multicolumn{1}{|c|}{ Correlation } & Sig. \\
\hline $\begin{array}{l}\text { Pair } \\
1\end{array}$ & PREKEMSEM \& & & & \\
\hline
\end{tabular}

3. Paired Samples Test

\begin{tabular}{|c|c|c|c|c|c|c|c|c|c|}
\hline & & \multicolumn{5}{|c|}{ Paired Differences } & \multirow[t]{3}{*}{$\mathrm{T}$} & \multirow[t]{3}{*}{ Df } & \multirow{3}{*}{$\begin{array}{l}\text { Sig. } \\
(2- \\
\text { tailed })\end{array}$} \\
\hline & & \multirow[t]{2}{*}{ Mean } & \multirow[t]{2}{*}{$\begin{array}{c}\text { Std. } \\
\text { Deviatio } \\
\mathrm{n}\end{array}$} & \multirow[t]{2}{*}{$\begin{array}{l}\text { Std. } \\
\text { Error } \\
\text { Mean }\end{array}$} & \multicolumn{2}{|c|}{$\begin{array}{c}95 \% \text { Confidence } \\
\text { Interval of the } \\
\text { Difference }\end{array}$} & & & \\
\hline & & & & & Lower & Upper & & & \\
\hline Pair 1 & $\begin{array}{c}\text { PREKEMSE } \\
\text { M - } \\
\text { POSKEMSE } \\
\text { M }\end{array}$ & $\begin{array}{c}- \\
35.067-\end{array}$ & 20.194 & 5.214 & $\begin{array}{c}- \\
46.250-\end{array}$ & $-23.884-$ & $\begin{array}{c}- \\
6.72 \\
6\end{array}$ & 14 & .000 \\
\hline
\end{tabular}

Berdasarkan hasil perhitungan Paired Sample Test pada tabel 8 bagian 3 mengenai perbedaan hasil pretes dan postes sikap kemandirian pada kelompok Sport Education Model. Diketahui ada perbedaan hasil pretes dan posttest sikap kemandirian pada kelompok Sport Education Model. Berdasarkan tabel di atas diketahui bahwa nilai $\mathrm{T}-6,72$ dan signifikansi $0,000<0,005$. Artinya $\mathrm{H}_{1}$ diterima yang menyatakan bahwa terdapat perbedaan hasil pretest dan posttes sikap kemandirian siswa yang mendapatkan perlakuan Sport Education Model.

Tabel 9

\section{Pengujian Hipotesis Model Konvensional Terhadap Sikap Kemandirian} dengan Menggunakan Uji T.

1. Paired Samples Statistics

\begin{tabular}{|cl|c|c|c|c|}
\hline & & Mean & N & Std. Deviation & Std. Error Mean \\
\hline \multirow{2}{*}{ Pair 1 } & PREKEMKON & 162.40 & 15 & 10.716 & 2.767 \\
& POSKEMKON & 192.47 & 15 & 13.658 & 3.527 \\
\hline
\end{tabular}


2. Paired Samples Correlations

\begin{tabular}{|ll|r|r|r|}
\hline & $\mathrm{N}$ & Correlation & \multicolumn{2}{|c|}{ Sig. } \\
\hline Pair 1 & $\begin{array}{l}\text { PREKEMKON \& } \\
\text { POSKEMKON }\end{array}$ & 15 & $-.046-$ & .871 \\
\hline
\end{tabular}

\section{Paired Samples Test}

\begin{tabular}{|c|c|c|c|c|c|c|c|c|c|}
\hline & & \multicolumn{5}{|c|}{ Paired Differences } & \multirow[t]{3}{*}{$\mathrm{T}$} & \multirow[t]{3}{*}{ Df } & \multirow{3}{*}{$\begin{array}{l}\text { Sig. }(2- \\
\text { tailed) }\end{array}$} \\
\hline & & \multirow[t]{2}{*}{ Mean } & \multirow[t]{2}{*}{$\begin{array}{c}\text { Std. } \\
\text { Deviation }\end{array}$} & \multirow[t]{2}{*}{$\begin{array}{l}\text { Std. Error } \\
\text { Mean }\end{array}$} & \multicolumn{2}{|c|}{$\begin{array}{c}95 \% \text { Confidence Interval } \\
\text { of the Difference }\end{array}$} & & & \\
\hline & & & & & Lower & Upper & & & \\
\hline Pair 1 & $\begin{array}{l}\text { PREKEMKON - } \\
\text { POSKEMKON }\end{array}$ & $-30.067-$ & 17.742 & 4.581 & $-39.892-$ & $-20.241-$ & $-6.563-$ & 14 & .000 \\
\hline
\end{tabular}

Berdasarkan hasil perhitungan Paired Sample Test pada table 9 bagian 3 mengenai perbedaan hasil pretes dan postes kemandirian pada kelompok model pembelajaran Konvensional. Diketahui ada perbedaan hasil pretes dan posttest sikap kemandirian pada kelompok Model Konvensioal. Berdasarkan tabel di atas diketahui bahwa nilai $\mathrm{T}$ 6.563 dan signifikansi $0,000<0,005$. Artinya $\mathrm{H}_{1}$ diterima yang menyatakan bahwa terdapat perbedaan yang signifikan hasil pretest dan posttes sikap kemandirian siswa yang mendapatkan perlakuan Model pembelajaran Konvensional.

\section{Tabel 10}

\section{Pengujian Hipotesis Perbedaan Pengaruh SEM dan Model Konvensional terhadap sikap tanggung jawab}

\begin{tabular}{|cl|c|c|c|c|}
\hline & \multicolumn{6}{c|}{ 1. Paired Samples Statistics } \\
\hline \multirow{2}{*}{ Pair 1 } & Mean & $\mathrm{N}$ & Std. Deviation & Std. Error Mean \\
\cline { 2 - 6 } & gainprepostjsem & 87.47 & 30 & 9.598 & 1.752 \\
& gainprepostjkon & 1.50 & 30 & .509 & .093 \\
\hline
\end{tabular}

\section{Paired Samples Correlations}

\begin{tabular}{|ll|r|r|r|}
\hline & \multicolumn{1}{|c|}{$\mathrm{N}$} & Correlation & \multicolumn{1}{c|}{ Sig. } \\
\hline Pair 1 & $\begin{array}{l}\text { gainprepostjsem \& } \\
\text { gainprepostjkon }\end{array}$ & 30 & $-.085-$ & .656 \\
\hline
\end{tabular}




\section{Paired Samples Test}

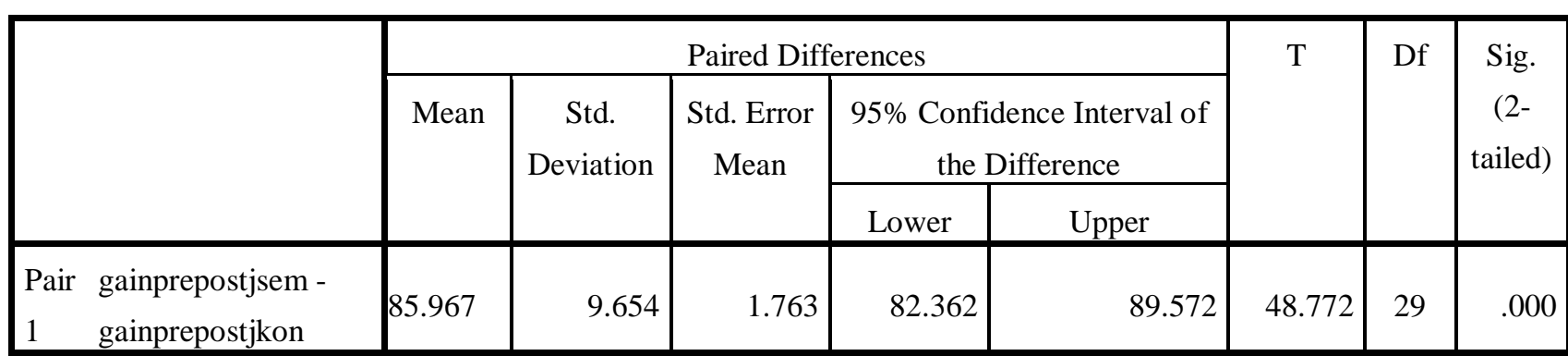

Berdasarkan

hasil

perhitungan Paired Sample Test pada

tabel 10 bagian 3 mengenai

perbedaan hasil belajar dengan

menggunakan Sport education

Model dengasn Model pembelajaran

Konvensional terhadap sikap

tanggung jawab siswa. Diketahui ada

perbedaan hasil posttes sikap

tanggung kelompok SEM dan

posttest sikap tanggung jawab pada kelompok Model Konvensioal.

Berdasarkan tabel di atas diketahui

bahwa nilai T 48.772 dan signifikansi

$0,000<0,005$. Artinya $\mathrm{H}_{1}$ diterima

yang menyatakan bahwa terdapat

perbedaan yang signifikan hasil

posttes sikap tanggung jawab

kelompok SEM dan posttes sikap tanggung jawab pada siswa yang mendapatkan perlakuan Model pembelajaran Konvensional.

\section{Tabel 11}

\section{Hasil Belajar dengan Model Sport Education Model dengan Konvensional Terhadap Sikap Kemandirian}

1. Paired Samples Statistics

\begin{tabular}{|cl|c|c|c|c|}
\hline & & Mean & N & Std. Deviation & Std. Error Mean \\
\hline \multirow{2}{*}{ Pair 1 } & Gainprepossemkem & 194.17 & 30 & 14.285 & 2.608 \\
& Gainpreposkonkem & 1.50 & 30 & .509 & .093 \\
\hline
\end{tabular}

2. Paired Samples Correlations

\begin{tabular}{|ll|c|c|c|}
\hline & $\mathrm{N}$ & Correlation & Sig. \\
\hline Pair 1 & $\begin{array}{l}\text { Gainprepossemkem }- \\
\text { gainpreposkonkem }\end{array}$ & 30 & $-.121-$ & .524 \\
\hline
\end{tabular}


3. Paired Samples Test

\begin{tabular}{|c|c|c|c|c|c|c|c|c|c|}
\hline & & \multicolumn{5}{|c|}{ Paired Differences } & \multirow[t]{3}{*}{$\mathrm{t}$} & \multirow[t]{3}{*}{ Df } & \multirow{3}{*}{$\begin{array}{l}\text { Sig. } \\
(2- \\
\text { tailed })\end{array}$} \\
\hline & & \multirow[t]{2}{*}{ Mean } & \multirow[t]{2}{*}{$\begin{array}{c}\text { Std. } \\
\text { Deviatio } \\
\mathrm{n}\end{array}$} & \multirow[t]{2}{*}{$\begin{array}{c}\text { Std. Error } \\
\text { Mean }\end{array}$} & \multicolumn{2}{|c|}{$\begin{array}{c}\text { 95\% Confidence } \\
\text { Interval of the } \\
\text { Difference }\end{array}$} & & & \\
\hline & & & & & Lower & Upper & & & \\
\hline $\begin{array}{l}\text { Pair } \\
1\end{array}$ & $\begin{array}{l}\text { gainprepossemkem } \\
\text { - gainpreposkon } \\
\text { kem }\end{array}$ & 192.66 & 14.356 & 2.621 & 187.306 & 198.027 & 73.51 & 29 & .000 \\
\hline
\end{tabular}

Berdasarkan hasil

perhitungan Paired Sample Test pada tabel 11 bagian 3 mengenai perbedaan hasil belajar dengan menggunakan Sport education Model dengan Model pembelajaran Konvensional terhadap sikap kemandirian siswa. Diketahui ada perbedaan hasil posttes sikap tanggung kelompok SEM dan posttest sikap tanggung jawab pada kelompok Model Konvensioal. Berdasarkan tabel di atas diketahui bahwa nilai $\mathrm{T} 73.508$ dan signifikansi $0,000<0,005$. Artinya $\mathrm{H}_{1}$ diterima yang menyatakan bahwa terdapat perbedaan yang signifikan hasil posttes sikap kemandirian kelompok SEM dan posttes sikap kemandirian pada siswa yang mendapatkan perlakuan Model pembelajaran Konvensional.

\section{PENUTUP}

Berdasarkan hasil pengolahan data dan analisis data, maka diperoleh jawaban pertanyaan penelitian yang diajukan. Kesimpulan atas jawaban pertanyaan penelitian adalah sebagai berikut:

1. SEM berpengaruh terhadap sikap tanggung jawab

2. Model konvensional berpengaruh terhadap sikap tanggung jawab.

3. SEM berpengaruh terhadap sikap kemandirian.

4. Model Konvensional berpengaruh terhadap sikap kemandirian.

5. Kedua model pembelajaran ini berpengaruh terhadap pembentukan sikap tanggung jawab. 
6. Kedua model pembelajaran ini berpengaruh terhadap pembentukan sikap kemandirian.

\section{DAFTAR PUSTAKA}

Abin, Syamsuddin Makmun. 2003. Psikologi Pendidikan. PT Rosda Karya Remaja, Bandung.

Frankel, J.R. dan Wallen, N. E. (1993). How to design and Evaluate Research in Education.San Francisco University.

Mahendra, Agus (2009). Implementasi Sport Education Model, (online). Tersedia di mahendra@blogspot.com/imple mentasi sport education.html [17 Maret 2014).

Perlman, Dana. (2012) The Influence of the Sport Education Model on amotivated students' in-class Physical Activihty. Jurnal ilmiah. European Physical Education Review.

Rochman, Taufik (2012). Pengaruh Model Hellison dan Kemampuan Kognitif Terhadap sikap Bertanggung Jawab Siswa SMP. POR Pascasajana UPI.Bandung.

Sugiyono. (2010). Metode Penelitian Kuantitatif, Kualitatif dan $R \& D$. Bandung: CV Alfbeta.

Suherman, Adang. (2009). Revitaslisasi pengajaran dalam Pendidikan Jasmani. Bandung. CV. Warli Bintang Artika. 
